\title{
Ismayıl Hakkı Baltacıŏlu'nun Özgün Eğitim Sistemi ve Bu Sistemin Zamanın Çağdaş Eğitim Yaklaşımları ile Karşılaştırılmasıı ${ }^{1}$
}

\section{Ismayıl Hakkı Baltacığlu's Original Education System and Comparison of This System with Modern Educational Approaches}

Okay DEMIR ${ }^{2}$

\section{Kemal DURUHAN ${ }^{3}$}

Alıntılama: Demir, O. \& Duruhan, K. (2019). Ismayıl Hakkı Baltacıŏlu’nun özgün eğitim sistemi ve bu sistemin zamanın çağdaş eğitim yaklaşımları ile karşılaştırılması. Ulusal Ĕ̆itim Akademisi Dergisi (UEAD), 3(1), 1-25.

Geliş tarihi:

20 Temmuz 2018

Kabul tarihi:

07 Kasim 2018

(C) 2019 UEAD.

Bütün hakları saklıdır.

Received:

20 July 2018

Accepted:

07 November 2018

(C) 2019 UEAD.

All rights reserved.
Özet: Ülkemizde sırasıyla Mutlakiyet, Meşrutiyet, Milli Mücadele, Cumhuriyet ve Çok Partili Hayat olmak üzere beş döneme şahitlik eden, aynı zamanda Avrupa'nın pek çok şehrinde eğitim amaçlı gözlemler yapan ve dönemin bir çok batılı ünlü eğitimcisi ile görüşmelerde bulunan Ismayıl Hakkı Baltacıŏglu kuşkusuz Türk eğitim tarihinde çok önemli bir yeri bulunan bir eğitim filozofudur. Bu çalışmanın amacı, Türk pedagojisine çok önemli katkıları olan Ismayıl Hakkı Baltacıŏ̆lu'nun eğitim yaklaşımını genel hatlarıyla ortaya koymak ve bu yaklaşımın diğer çağdaş eğitim yaklaşımları ile arasındaki farklılıklara değinmektir. Bu amaca uygun olarak Baltacıoğlu'nun eğitim alanında ortaya koymuş olduğu eserler, onun eğitim anlayışını yansıtan teorik çalışmalar ve karşılaştırılmak istenen çağdaş eğitim kuramları incelenerek bir derleme çalışması ortaya konulmuştur. Baltacıoğlu'nun İçtimai Mektep sisteminin batılı çağdaş eğitim anlayışlarına kıyasla bir çok farklılıklara sahip olduğu ve ilkelerinin bütünü göz önüne alındığında özgün bir eğitim sisteminin olduğu sonucuna ulaşılmıştır.

Anahtar kelimeler: Ismayıl Hakkı Baltacıoğlu, çağdaş eğitim akımları, içtimai mektep

\begin{abstract}
There is no doubt that Ismayıl Hakkı Baltacıoğlu is one of the most important education philosopher who witnessed the periods of autocracy, constitutional monarchy, war of independence, establishment of Turkish Republic and multi-party system respectively. He is also known as one of the educators who made observations in different countries of the world by meeting with many important Western educators. The aim of this study is to describe Ismayıl Hakkı Baltacıoğlu's educational approach that contributed considerably to Turkish education system and to compare his approach with other modern educational approaches. In accordance with this aim, Ismayıl Hakkı Baltacıoğlu's studies on education, his theoretical works and contemporary institutions that are included into this study to be compared are examined. It is concluded that Baltacioğlu's Social Education System has many differences compared to Western modern education. It is also concluded that his system is totally an original one when his principles are taken into consideration.
\end{abstract}

Keywords: Ismayıl Hakkı Baltacıŏlu, contemporary educational approaches, social school

\footnotetext{
${ }^{1}$ Bu çalışma, birinci yazarın İönü Üniversitesi Eğitim Bilimleri Enstitüsü’nde yapmış olduğu doktora tezinin bir bölümünü içermektedir.

2 (Sorumlu Yazar), Dr, MEB, okay4425@gmail.com, https://orcid.org/0000-0001-8033-3355.

${ }^{3}$ Prof. Dr., Inönü Üniversitesi, kemal.duruhan@inonu.edu.tr, https://orcid.org/0000-0001-5675-4467.
} 


\section{Giriş}

Çağdaş Türk eğitim tarihi geçmişten günümüze doğru incelendiğinde, kendine özgü fikirleriyle tanınmış pek çok eğitim felsefecisi bulunmaktadır; ancak bunların arasında belki de felsefi değeri en yüksek düşünürlerimizin başında Ismayıl Hakkı Baltacıoğlu gelmektedir. Ülken (1998)'e göre, Baltacığlu, kendinden sonraki nesillerin pedagojik çalışmalarının hareket noktası olmakla birlikte, orijinal görüşünün izinden gidenler bulunmamaktadır; ancak mektepçiliği, sonraki nesillerin ve başlıca ilk öğretmen okulları pedagoji öğretmenlerinin yetişmesinde rehber olmuştur. Baltacıoğlu'nun eğitime ilişkin görüşleri genel itibariyle incelendiğinde, günümüzde bu görüşlerin önemli ölçüde geçerliliğinin devam ettiği söylenebilir. Ergün (1996)'e göre Baltacıoğlu'nu diğerlerinden ayıran faktörlerin başında; kendi zekâ, yetenek ve ruh yüceliği ile hem Avrupa'yı hem de Osmanlı ve Cumhuriyet devirlerini yaşaması bağlamında yetiştiği ortam gelmektedir.

Toplumsal kalkınmanın temelini eğitim olarak gören Baltacıŏglu’na göre, ülkemizde eğitimin amacı "uslu, hafızası kuvvetli adamlar yetiştirmek" biçiminde algılanmakta, eğitim inançlarımız hurafelerden oluşmaktadır. "Hâlbuki insanların hayatındaki başarı; birinci derecede bildiklerinin ve zekâlarının değil, teşebbüs, azim, dayanıklılık, cesaret ve gözü peklik gibi ahlaki vasıflarının, yani karakterlerinin ürünüdür“" (Baltacıoğlu, 1995).

Baltacığlu, Tanzimat'tan beri okul isteyen milletimizin, esasında hangi okulu arzu ettiğini bilmediğini belirtmektedir. Ona göre, yakın tarihimizde üç tip okul yer almıştır. Bunlar: Mahalle Mektebi, Meşrutiyet Mektebi ve Cumhuriyet okuludur. Mahalle Mektebi, görenekçi bir okuldur, hürriyet düşmanı ve ezberci olup bir medrese yavrusundan başka bir şey değildir. Mahalle mektebi çocuğun kişiliğini hiçe sayar, dayak atar, dayağı eğitim aracı sanır ve okumayazmadan başka hiçbir şey öğretmez. Meşrutiyet mekteplerinin yeni binaları vardır; kendilerine göre hür disipline yer verirler; birtakım yenilikler taşımakla birlikte yine de gerçek bilgiyi veremeyen, yaratıcı insan kişiliğini yetiştiremeyen mekteplerdir. Cumhuriyet devrinde ise okulların,öğretmenlerin, öğrencilerin, öğretim araçlarının sayısı artmıştır; ancak o da Meşrutiyet mektebi gibi görenekçilikten kurtulamamış, okutma, anlatma ve ezberletmeyi temele almıştır (Baltacioğlu, 1964).

Baltacıŏglu, bugünkü cemiyetin muhtaç olduğu insan tipini yetiştirmek için, milletin kültürünü ve zamanın tekniğini dikkate alarak fertleri, gerçek çevreler içerisinde, kendi 
çalışmaları ile sosyal randımanlar verdirerek yetiştirmek gerektiğini düşünmektedir (Tozlu, 1989). Bu konuda şunları söylemektedir (Baltacıŏglu, 1964:54):

1. Her eğitim kurumu belli bir iş öbeğine adam yetiştirmek için vardır.

2. Her eğitim kurumunun başka eğitim kurumlarındaki ile karışmayan, kendine göre bir görevi vardır.

3. Toplum için yararlı olmayan eğitim kurumları hastadır. Bunlar topluma "sağlam adamlar" yerine, "köksüzler” denilen hasta tipleri yetiştirirler.

4. Her türlü reform işinde olduğu gibi eğitim reformunda da amaç, toplumun kendisi olmalidir.

Baltacıoğlu (1964)'na göre geçmişten bugüne, eğitim deyince insanların aklına “adam yetiştirmek" gelmektedir. Oysaki gerçekte "adam” yok, "adamlar" vardır. Burada "adam" kavramı soyut bir kavram değil, gerçek toplumların gerçek insanları demektir. Böyle olunca eğitimin amacı "adam yetiştirmek" olmayıp belli bir toplumun belli adamını yetiştirmek olabilir.

İçtimai Mektep isimli eserinde terbiyeyi, içtimai (sosyal) bir amacın gerçekleşmesine çalışmakla betimlemektedir. Baltacıoğlu'na göre bu amaç, düşünme, duyma ve işleme tarzlarına sahip bir insan vücuda getirmektir ve bu amacın cemiyet haricinde hiçbir anlamı bulunmamaktadır. Çünkü bu amaç bizzat cemiyetin amacıdır. Bu noktada terbiye, içtimai bir kimlik hazırlamalıdır ve bu içtimai kimlik henüz terbiye almamış insanda yoktur (Baltacıŏlu, 1932a). Sonuç itibariyle Baltacıŏglu nezdinde milli kişilik ile teknik kişiliği sağlayamayan eğitim sakat olup esas amacından sapmış görünmektedir. Bu noktada Baltacıoğlu'nun eğitim sisteminin temeli olan İçtimai Mektep ilkelerine değinmek gerekmektedir. Baltacıoğlu'nun, bu temel ilkeleri öncelikle "İçtimai Mektep" adlı eserinde ele aldığı; ancak daha sonra ilkelerinin isim olarak tasnif edilmesi ve uygulama boyutunun bir kısmının "Toplu Tedris" adlı eserinde yer aldığ görülmektedir. Aytaç (1984)'a göre, İçtimai Mektebin felsefi temelini “Şahsiyet Pedagojisi”" teşkil etmektedir. Şahsiyet pedagojisi görüşünde Baltacıoğlu, eğitimi bir teori olarak değil, bir olgu olarak ele almaktadır. Bu olguyu psikolojik ve sosyolojik verilere dayandırarak temellendirmekte ve böylece de eğitimin sosyal bir olgu olduğu sonucuna ulaşmaktadır. İçtimai Mektep (1932a) adlı kitabında eğitim sistemlerini ayrı ayrı inceleyip eleştirdikten sonra kendi temel ilkelerini açıkladığı ve tüm bu ilkelerin "Şahsiyet Pedagojisi" ni oluşturduğu ve bu pedagojiyi uygulayan okula da “İçtimai Mektep” dediği görülmektedir (Baltacıoğlu, 1932a). 
Alanyazın incelendiğinde, Baltacıoğlu'nun eğitim anlayışını içeren birçok çalışmanın olduğu; ancak bu çalışmalarda genel itibariyle Baltacıŏlu'nun eğitim sisteminin tanıtıldı̆̆ı ve bu sistemle çağdaş eğitim yaklaşımlarının karşılaştırılmasının yapılmadığı görülmektedir. Bu çalışmanın amacı, Türk pedagojisine çok önemli katkıları olan Ismayıl Hakkı Baltacıoğlu'nun eğitim yaklaşımını genel hatlarıyla ortaya koymak ve bu yaklaşımın diğer çağdaş eğitim yaklaşımları ile arasındaki farklılıklara değinmektir. Bu amaca uygun olarak yapılan bu derleme çalışmasında öncelikle Baltacıoğlu'nun eğitim alanında ortaya koymuş olduğu eserler ile onun eğitim anlayışını yansıtan teorik çalışmalar başta olmak üzere, karşılaştırılmak istenen çağdaş eğitim kuramları da incelenmiştir. Böylece, diğer çağdaş eğitim yaklaşımları ve Baltacıoğlu'nun eğitim sistemi birlikte değerlendirilerek, sistemin uygulanabilirliğini görmek açısından alanyazına katkı sağlanacağı düşünülmektedir.

\section{Baltacıoğlu'nun İçtimai Mektep İlkeleri}

Baltacıoğlu'nun birinci ilkesi Şahsiyet olup öncelikle şahsiyeti tarif etmekle bu kavramın önemine işaret etmektedir. Baltacıoğlu'na göre şahsiyet: "Demirin mukavemeti, tahtanın fiyatı, şeytani kuvvetlerin baştan çıkarması gibi muayyen harici kuvvetler karşısında içtimai bir tepki vücuda getirmeye yani ahlaki, estetik, lisani, yahut zirai, ticari ve sinai, hulasa yaratıcı, mürekkep neviden bir mukabeleye muktedir olan şey” demektir. Bunun için Baltacıŏ̆lu'na göre eğitimin amacı, canlı, estetik, ahlaki ve mesleki şahsiyetlere mahsus olan tepkiler manzumesi oluşturmaktır (Baltacıŏlu, 1942:23). Ona göre eğitimciler, şahsiyetin bütünlüğünü gözden kayıp etmemelidir. Çocuğun bir alim, bir demirci, bir çiftçi vs. gibi gerçek şahsiyetler haline gelmesi için, verilmesi gereken hususları iyi takip etmelidirler. Yani gerçek cemiyet içerisinde yaşayan ve var olan gerçek adamlar ölçü olarak alınırsa, bunların bir meslek adamı olduğu görülür. Bunlar cemiyet şahsiyetleriyle ayrılan “içtimaîleşmiş” fertlerdir (Tozlu, 1989). Aytaç (1984)' a göre bu ilke ile eğitimin amacı doğrultusunda gerçek kişilikler yaratılmalı, eğitim ve öğretim insana bir alanın yalnız bilgisini vermekle kalmamalı, o konunun kişiliğini de kazandırmalıdır. Örneğin eğitim insana sanatın bilgisini vermekle kalmamalı, insanın sanatkâr kişiliğini de geliştirmelidir. Nitekim Baltacıoğlu da, İçtimai mektep adlı eserinde, gerçek şahsiyetler ve bu şahsiyetlerin vazifelerinin, gerçek cemiyetlerin doğal ve asli müesseseleri içinde yapılan gerçek ve tam faaliyetlerle oluşabileceğini belirtmektedir (Baltacıŏlu, 1942). Baltacıoğlu'nun eserlerinde kişiliği, milli ve teknik kişilik olmak üzere iki kısma ayırdığı görülmektedir. Genel itibariyle, 
milli kişiliği var eden, milli kültür denilen değerler yani dil, din ve sanattır. Teknik kişiliği var eden ise teknik denilen kurallardır. Bunlar; fizik, kimya, biyoloji, psikoloji, sosyoloji bilimleri ile bu bilimlerin uygulanmasından meydana gelen fenler, zanaatlar ya da deneysel bilgilerdir (Baltacioğlu, 1964).

Baltacıoğlu'nun ikinci eğitim ilkesi ise muhit ilkesidir. Baltacıoğlu (1964)'na göre, her eğitimin meydana getirmek istediği bir kişilik olup bu kişiliğin içinde meydana gelebilecek bir muhit, bir çevre vardır. Bu çevre ya bir kültür çevresi ya da bir teknik çevresidir. Onun için her çevre, içinde verilebilecek olan eğitimin tabiatına uygun olmalıdır. Eğitim almak durumunda olan insanın böyle bir çevre içinde yaşaması gerekmektedir. Şu halde fert hangi mesleğe müsaitse, o mesleğin çevresinde, mesleğin teknik ve kıymetleriyle yaşatılmalı, okul bu açıdan küçük çapta meslek çevrelerine ayrılmalı, böylece gerçek şahsiyetlerin oluşumunu sağlayacak çevreler hazırlanmalıdır (Tozlu, 1989). Baltacıoğlu, bu ilkesinin daha iyi anlaşılabilmesi için kavramlardan yola çıkarak çeşitli örnekler vermektedir. Örneğin öğrencilere, muhit prensibine göre topluluk terbiyesi vermek istersek, okulu sosyal gruplara ayırmamız ve bu grupları sayıca çok ve canlı hale getirmemiz gerekmektedir. Yine muhit prensibine göre çocuklara tarih öğretmek istiyorsak, yazılı eserlerin, kitabelerin, abidelerin, antikaların, yerinde veya tarih laboratuvarında incelenmesi gerekmektedir (Baltacıoğlu, 1938a).

Baltacıoğlu'nun üçüncü eğitim ilkesi ise travay (çalışma) ilkesidir. Baltacıoğlu (1964)'na göre, yeni eğitim çevreleri kurmak yetmemekte, bu çevreler içinde yetişecek olan insanların çevre yaşayışına aktif olarak katılmaları da gerekmektedir. Bu katılma yalnız zekâ ve hafıza ile olmamalı, kişiliğin tümü ile olmalıdır. Çünkü insan yalnız zekâsı ile düşünmez, yalnız gönlü ile duymaz, yalnız istemi ile çalışamaz. Düşünen de, duyan da insanda kişilik denilen bir bütündür. Çocuk sosyal cinsten gerçek çevrenin içinde seyirci durumunda kalmamalıdır. Böyle bir durumun eğitim açısından hiçbir değeri bulunmamaktadır. O yüzden, travay prensibinden maksat bireyin, gerçek sosyal faaliyete katılmasıdır. Bu ilkenin daha iyi anlaşılması için şu örneği vermektedir: “İçtimai Mektepte yetişenler tarlada çalışanları seyretmezler, tarlada çalışırlar” (Baltacıŏlu, 1944:98).

Gerçek çevrelerde, gerçek çalışmalarla yaparak yaşayarak öğrenmeyi önemsediği görülen Baltacıŏglu'nun yapay çalışmaları şiddetle eleştirdiği görülmektedir. Örneğin, kâğıttan fener veya vazo yaptırmak gerçek bir teknik değildir. Gerçek insana gerçek aletler yaptırılmalıdır. Deneyleri ve araştırmaları öğrenci yapacaktır. Bilimsel ve sanatsal şahsiyetleri meydana getiren sebep 
onların kendilerine has olan tekniği olup bu teknikte iktisadi, maddi ve mesleki zaruretlerin bir sonucu ve ifadesidir. Böylece Baltacıŏglu'nun sistemiyle çalışma fikri, hem bütün bir sosyal vazife faaliyeti fikri, hem de gerçek bir teknik ve alet fikri taşımaktadır (Tozlu, 1989).

Baltacıŏ̆lu'na göre çalışmalar dört türlüdür (Baltacıoğlu, 1964:111-113):

1. Anarşik çalışma devresi: Çalışmanın ilk şekli olup emeklemeye başlayan küçük çocuğun çalışması gibidir. Öğrenmeye başlayan çırağın, hiçbir randıman vermeyen, otomatik çalışması böyledir. Bütün çalışmalar bu devre ile başlar. Bu başlama olmadıkça hiçbir çalışma evrimi olamaz.

2. Mekanik çalışma devresi: Bireyin bilmeden, anlamadan, gördüğü, alıştığ1 gibi çalışması böyledir. Bu çalışma türünde randıman vardır; ancak bu randıman hiç değişmez. Evinin yemeklerini gördüğü gibi, alıştığı gibi yapan, modaya olduğu gibi uyan, okulda aldığ1 dersleri ezberleyen, Batı bilimlerini olduğu gibi taşıyan yazarın, ressamın, mimarın, bilimcinin, felsefecinin, çırağın çalışması böyledir.

3. Aktif çalışma: Bütün yaptıklarını bilerek, anlayarak yapan, gördüğü, alıştığı gibi değil, başarılı bulduğu için yapan, kendi alanında kendine göre değişiklikler yapan, ufak çapta yenilikler meydana getiren, kazandığı bilgiler üzerinde düşünen, bilgisi ile işi arasında bağlantı sağlayan öğrencinin, teknik adamın, fikir adamın çalışması böyledir. Bu tip insanlar dördüncü tipe atlamak yeteneğinde olan ancak bunu yapmak yolunu bulamayan talihsiz insanlardır. Işıldayıp ışıldayıp sönen, bütün parlaklığı ile uçup giden yıldızlara benzerler.

4. Yaratıcı çalışma: Çalışmanın en yüksek, en verimli türüdür. Büyük sanatçıların, büyük bilginlerin, büyük filozofların, büyük teknisyenlerin çalışması böyledir. $\mathrm{Bu}$ insanların zekâsı tabiatın sırlarına kadar ulaşır, görülmeyeni gösterirler, duyulmayanı duyururlar, olamaz sanılanı oldururlar. Kendilerinden önce bilinen, duyulan gerçekleri tanımakla kalmazlar, yepyenilerini ortaya koymak için eskilerini alet olarak kullanırlar. Bu insanlar kendilerini başkaları için yaşatan insanlardır.

Baltacıŏ̆lu'na göre, çalışmaktan çalışmaya elbette fark olmaktadır. Örneğin, öğrenciler, dört köşesi olan bir odanın duvarlarına hazır duvar kağıdı koymak ya da bu duvar kâğıdı yerine renk seçimi yaparak bir yağlı boya sürmek isteyebilir ve bu durum öğrenciyi zihnen çalışmaya götürür. Öğrenci bu duvarları kendi kompozisyonuyla süslemek isterse mesele daha çok çetinleşir. Bu kompozisyonun kübizm zevkine göre olması işi daha karmaşık bir hale getirir. $\mathrm{Bu}$ 
işler derece derece faal, yaratıcı işlerdir. Diğer bir örnek olarak, öğrencilerin bir tiyatro yazarının eserini temsil ettiklerini düşünelim. Burada öğrencilerin faal olan şahsiyetleri aktör şahsiyetleridir. Hâlbuki yazar şahsiyetleri doğrudan doğruya faaliyete getirilmiş değildir. Eğer öğretmen sıfatıyla çocuklara yazar terbiyesi verilmek isteniyorsa onları faal bir travaya sevk etmek gerekmektedir. Bu faal travay ise tiyatro senaryoları hazırlamak tecrübesi olabilir. $\mathrm{Bu}$ tecrübeler ne derece ilkel ve mütevazı olurlarsa olsunlar, yine öğrenciyi yaratıcı faaliyete sevk ettikleri için önemlidirler (Baltacıoğlu, 1938a).

Baltacıoğlu'nun dördüncü eğitim ilkesi ise randıman (verim) ilkesidir. Gerçek bir çalışmanın şartı, elbette gerçek bir eser, bir randıman elde etmektir. Gerçek randımandan maksat sosyal değer taşıyan bir eser demektir. Yani terbiyeye konu olan insan, gerçek bir hayat çevresinde yaşayacak, gerçek bir çalışma yapacak ve mutlaka gerçek bir eser verecektir. Baltacıoğlu (1942)'na göre, randıman prensibi, çocuğun faaliyetini sosyeteye bağlayan sağlam bir bağ olmakla birlikte bu ilke, yalnız iş, teknik, ekonomik ve artistik faaliyetlere değil, insan faaliyetinin bütün alanlarında uygulanabilir. Örneğin Baltacıoğlu'na göre, randıman prensibinin faaliyet terbiyesine uygulanmasının sonuçları şunlar olabilir: Öncelikle öğrencinin yapacağı bütün işler onun hayatının ihtiyaçlarından alınmış mevzulardan olmalıdır. Bu mevzular yapılır yapılmaz günlük ihtiyaçlar için kullanılmalıdır. Bu işleri yapmak için sarf edilen sermaye, emek ve neticede elde edilen değer, toplumda sarf edilenlerden ayrı olmamalıdır. Bir masa, bir sandalye, bir kızak, bir pervane vs. gerçek randımanlardır. Samandan iskemle, mukavvadan araba, kâğıttan saat, tenekeden bel ve kürek vs. yalancı işlerdir (Baltacığlu, 1938a).

Baltacioğlu'nun beşinci eğitim ilkesi ise inisiyasyon (allşstırma, başlatma) ilkesidir. Baltacioğlu (1964)'na göre eğitimin, adam yetiştirmenin bir ilkesi de inisiyasyon, yani başlatmadır ve bu ilke İçtimai Mektep ilkelerinin beşincisi ve sonuncusudur. Hangi tür çalışmalar istenilen kişilikleri yaratmanın başlangıcı olacaktır? $\mathrm{Bu}$ çalışmalara ana çalışmalar, temel çalışmalar, başlatıcı, alıştırıcı çalışmalar da denilebilir. Bu çalışmalar her eğitim konusuna göre, başka türlü olacaktır. Terbiye, bireyleri toplum hayatına hazırlamak amacındadır; ancak bu hazırlamayı okulun zaman ve mekân bakımından tamamıyla sunması mümkün değildir. $\mathrm{O}$ halde yapılacak olan şey bu kısa zaman ve dar mekânda çocuğu toplumun gerçek hayatına hazırlamak için zaruri ve mümkün olanı yapmaktır. Çocuklara okul çevresi içerisinde yaptırılması mümkün olan hayat tecrübelerinin toplamına "inisiyasyon" denmektedir (Baltacıoğlu, 1942). Baltacıoglu (1944)'na göre terbiye, bir inisiyasyondur, her şey değildir. Terbiye, çocuğa sosyal insanın bütün 
alışkanlıklarını kazandıramaz, yalnızca sosyal hayata başlatabilmektedir. Örneğin ziraat terbiyesinin inisiyasyonu bellemek, dikmek, budamaktır. Nutuk ve hitabet terbiyesinin inisiyasyonu doğaçlama yapabilmektir. Marangozluk terbiyesinin inisiyasyonu rendelemek ve diş açmaktır (Baltacıoğlu, 1944). Ancak tabi ki öğretmen bütün bunları yaptırırken öğrencilere yardımcı olmalıdır. Bu "yardım” sözündeki amaç, öğrencinin yerine geçmek, onun yerine çalışmak, onun kendi kendine yapacağını yapmak değil, ona şahsi, hür ve acemi faaliyetlerini yapmada yardımcı olmaktır. Bu görev, başlatmak, yoluna koymak, kılavuzluk, ustalık, işbaşılık, hocalık etmek diye anlaşılmalıdır. Öğretmen, okulda kümes, arı kovanı gibi aletleri hayatın gerçek ihtiyaçları haline getirecek bir toplum çevresi kurarken, bunların yapılmasına yarayan tekniği bildirirken, bu eserlerin sosyal çevre için değer olmasını sağlarken bir şef, bir teknisyen gibi öğrenciye yardım edecektir. Aralarında daima usta-çırak, ergin-acemi ilişkisi bulunacak, yetiştiricilik onun en temel rolü olacaktır. İnisiyasyon prensibinin örnek olarak faaliyet terbiyesine uygulanmasında öğretmenlerin görevi için şu sonuca varılabilir: öğretmen sosyal bir faaliyet çevresinde, sosyal bir teknikle, sosyal randımanlar vermek üzere çalışan acemilerin sosyal faaliyet şahsiyetini kazanmaları için bir yardımcı gibi olmalıdır (Baltacıoğlu, 1938a).

İnisiyasyon esas itibariyle, okulları gerçek hayatın, gerçek vazifelerine hazırlamak için, okulda yapılacak gerçek faaliyetlerin derecesini kararlaştırmaktır. Öğrenciyi bir yüzgeç kadar yüzücü, bir çilingir kadar demir işleyici ve bir çiftçi kadar toprağa hâkim yapmak son derece zordur. Bu duruma ne çocuğun gücü, ne de okulun imkânları yeter. Bununla birlikte, çocuklara yaptırılacak faaliyetlerin gerçek cinsten olmaları bir zarurettir. Gerçek faaliyetlerin öyle parçaları alınmalı ki, bunları yapmak sayesinde çocuk en geniş ve en büyük cinsten olan sosyal faaliyetlere hazırlanmış olsun. $\mathrm{Bu}$ cins hazırlayıcı faaliyetlere "inisiyasyon faaliyetleri" denebilir (Baltacioğlu, 1938a:26-27).

\section{Baltacıŏ̆lu'nun İçtimai Mektep Modelinin Diğer Çağdaş Eğitim Modelleri ile Karşılaştırılması}

Baltacıŏ̆lu'na göre İçtimai Mektep sistemi, birbiriyle bağlantılı olan "şahsiyet, muhit, travay, randıman ve inisiyasyon" ilkelerini içeren felsefi bir sistemdir (Baltacıoğlu, 1964). Baltacıoğlu, İçtimai Mektep sistemini ortaya koyarken, klasikçilerden başlayarak, bireyciler, hümanistler, parçacılar, rasyonalistler, sezgiciler, kavramcılar, şuurcular, anarşistler, faaliyetçiler ve bütüncüler olmak üzere, bu pedagojik sistemleri incelemiş ve bu pedagojik sistemlerin çeşitli yönleriyle eksik olduğuna kanaat getirmiştir (Baltacıŏlu, 1942). Esasında Baltacıoğlu'nun en 
çok etkilendiği düşünür Rousseau'dur. O kadar ki, Baltacıoğlu'na göre, Rousseau gibi bir dehayı yetiştirmek her milletin, her yüzyılın işi değildir. Rousseau'dan sonra gelenler, onun ne sezgisini ne de tümleme gücünü taşımıştır. Rousseau gölü taşınca da, kollara ayrılmış, Kant, Pestalozzi, Froebel, Tolstoy, John Dewey, Montessori gibi düşünürler bu kaynaktan gelmişler; ancak Rousseau gibi diri ve genç kalamamışlardır. Örneğin Kant pedagoji tarihinde disiplinin, baskının en büyük örneği olup baskıdan anladığı tabiatı zorlamaktan başka bir şey değildir. Pestalozzi de Rousseau gibi tabiatçıdır ancak $\mathrm{O}$, çocukta evrimin yalnız içeriden dışarıya doğru değil, yavaş yavaş, adım adım, parça parça olacağına inanarak parçacı bir pedagojiyi takip etmektedir. Pestalozzi'den sonra gelen Froebel ise her ne kadar çocuğun yaratıcılığını ön plana çıkararak eğitim felsefesini zirvelere taşısa da eğitim uygulamalarında arzu edilen başarıyı gösterememiştir. Tolstoy ise çocuğun evrimini doğru anlamış ve yorumlamıştır, ancak bireydeki isteklerin, özlemlerin hangi kaynaktan geldiği noktasını tam olarak aydınlatamamıştır. Dewey ise belki de üzerinde en çok durulması gereken filozoftur. Ona gelinceye kadar hiçbir eğitimci eğitimin sosyal yönü ile onun kadar yakından ilgilenmemiştir. Bununla birlikte teori alanında bu kadar ileri giden, olumlu görünen Dewey'in pedagojisi, uygulama alanında randımanını tam olarak verememekte, aksamaktadır. Dikkate değer bir eğitimci olan İtalyalı Montessori ise zengin bir evrim sezgisine sahip olmakla birlikte, uygulama alanında Pestalozzi, Froebel göreneğine saplanarak çıkmaza girmektedir (Baltacıŏglu, 1964:66-73).

Tozlu (1989)'ya göre, tüm bu açıklamalar incelendiğinde, Baltacıoğlu’nun İçtimai Mektep sistemi ancak "Çocuktan hareket", "İş okulu” ve "Üretim okulu” akımlarıyla mukayese edilebilir. Aşağıda bu yaklaşımlar ile Baltacıoğlu'nun eğitim sisteminin karşılaştırılması bulunmaktadır.

\section{1. "Çocuktan Hareket” Akımı ve Baltacıoğlu}

Çocuktan hareket akımı, çağdaş eğitim reformu akımlarının başlangıcına ve ilk devresine (1900'lerden 1914'lere kadar) damgasını vurmuştur. Çocuk bu dönemde sanki yeniden keşfedilmekte ve her türlü eğitim ile öğretimin merkezinde yer almaktadır. Bu akımla eğitim, kendisine çocukta yeni bir yönelme bulmaktadır. Daha önceleri eğitimin amaç ve içeriklerini “toplum”, “yetişkinler” ve “objektif değerler” gibi unsurlar belirlerken, belirleyici unsur artık “çocuk" olmaktadır (Aytaç, 2006).

Çocuktan hareket akımı çocuğu Rousseau'nun anlayışıyla ele almaktadır (Aytaç, 2006). Rousseau "Emile" adlı eserinde, "tabii insanı" yaratacak olan bir eğitimden bahsetmektedir. Ona göre çocuklar, yeteneklerini ortaya çıkarmaları ve olmak istedikleri şeyi olmaları için özgür 
bırakılmalıdır. Çocuklar her şeyi deneyerek öğrenmelidirler (Rousseau, 2013). Aytaç (2012)‘a göre, Rousseau'yu kendinden önceki pedagoglardan ayıran en önemli hususlardan birisi, çocukların ruhsal ve vücutsal tabiatlarının engellenmeden geliştirilmesine ve vaktinden önce dışarıdan yapılacak her türlü müdahalelerden korunmasına verdiği önemdir ve Rousseau, Emile adlı eserinde bireyci bir eğitim modeli sunmaktadır. "Emile" adlı çocuk, sarayda kendisinin eğitimi ile uğraşan eğiticisiyle birlikte, insanlardan ve toplumdan uzak olarak yetiştirilmektedir Çocuk dışarıda ve kırlarda sıhhatli ve tek başına yaşatılmaktadır (Rousseau, 2013). Bu bireyci eğitim şu ana görevleri yüklenmiştir (Aytaç, 2012:187):

- Eğitimin ilk görevi tabiatın, çocuğun gelişim yoluna engel olarak çıkan her şeyi ortadan kaldırmaya çalışmasıdır. Ancak bu sayededir ki çocuk, kendi tabiatı ve ihtiyaçları doğrultusunda serbestçe hareket edebilmiş olur.

- Eğitimdeki geleneksel baskı metodu terk edilmelidir. Baskı, bir eğitim vasıtası olarak ortadan kaldırılmalıdır. Çocuklar baskı yoluyla değil, yalnızca açıklamalar yoluyla yönetilmelidir.

Baltacıŏglu (1942)'na göre de, çocuğu çocuk olarak ele alan terbiye tarzının öncüsü Rousseau'dur. "Terbiyesini unutan insanlar vardır; tabiatı tetkikle işe başlayın, zaruret kanununu zorlamayın; terbiyede hüner vakit kazanmak değil, vakit kaybetmektir” diyen ve böyle diyerek pedagoji tetkiklerini çocuğun ruhi tabiatından ibaret objektif bir gerçek üzerine götüren Rousseau'dur. Pedagojide gerçek bir devrim yaratmış olan Rousseau'nun, beden eğitimine önem vermesi, çocuğun iç tabiatına uygun eğitimin verilmesini ve çocuğun ruhunu ve yeteneklerini araştırmanın gerekliliğini öne sürmesi, sezgiye, kendi kendine etkinlik ilkesine, çocukta ilgiye, zanaat ve el işlerine önem vermesi gibi dikkate değer görüşleri bakımından, etkisi bugünlere kadar gelmiştir (Kanad, 1963).

Çağdaş eğitim reformcuları arasında öğretimi, çocuğun kendi kendine ilkesine dayandırarak kendine has bir öğretim sistemi yaratan kişilerden biri de M. Montessori'dir (Aytaç, 2006). Montessori felsefesinin eğitim anlayışı, çocukların ileride ortaya çıkacak olan tüm özelliklerinin aslında onlarda zaten var olduğu temeline dayanmaktadır. Bir çocuğun fiziksel, zihinsel ve ruhsal potansiyelinin tam anlamıyla gelişebilmesi için mutlaka o çocuğun özgürlüğünün olması gerekmektedir. Montessori eğitim yönteminin kendine özgü özellikleri şunlardır (Aydın, 2010:62-64): 
- Montessori sınıfları üç yaş grubunun bir arada bulunduğu ortamlardır. Okul öncesi 3 ve 4 yaş çocukları ile anaokulu öğrencilerini; ilköğretim okulları ise 1., 2., 3. sınıf öğrencileri ve diğerlerini kapsar. Farklı yaş grubundan olup aynı sınıfı paylaşan öğrenciler üç yıl aynı öğretmende kalırlar. Çocukların karışı yaş biçiminde gruplanması, Maria Montessori'nin üç yıllık periyotlara dayanan çocuk gelişimi teorisine dayanır.

- Montessori eğitim materyalleri özeldir. Materyaller, çocukların bireysel ve küçük gruplar halinde çalışmalarını sağlamak üzere geliştirilmiştir. Örneğin, Matematik dersinde materyaller ondalık ve kesir gibi matematik kavramlarını temsil eder. Coğrafya dersinde öğrenciler bulmaca haritaları ile çalışırlar.

- "Hazırlanmış çevre" olgusu önemlidir. Bu, belirli bir düzenin olduğu, çocukların kendi hızlarında ve kendi kapasitelerine göre öğrenebilecekleri, rekabetin olmadığ bir ortamdır. Çocuk, o ortamda başarılı olmak için birçok olanak elde eder.

Baltacioğlu (1964)'na göre, Montessori dikkate değer bir eğitimci olmakla birlikte "Kertenkelenin, kuşun tabii bir çevresi varsa, insan yavrusunun da tabii bir çevresi olmalıdır. Bu çevre, Case dei Bambini, yani çocukların yuvası olacaktır" düşüncesi takdire şayandır. Montessori, çocukların bu yuvada yaşayacaklarını, burada gelişeceklerini, burada adam olacaklarını öne sürmektedir. Kendisi, çocukların kişiliklerini burada yaratacağına inanmaktadır. Ancak uygulamada, çocukların gözlerini bağlamakta, kumaş parçalarını yoklatmakta, takozları birbirinin içine sokturmakta, çocukları tek ayak üzerinde durdurmakta ve onları susmaya zorlamaktadır. Bu zengin eğitim felsefesinden sonra uygulama alanında kötürüm olan, sürünen bir pedagoji ortaya çıkmaktadır.

“Çocuktan Hareket" akımı ile Baltacıŏglu'nun İçtimai Mektep sistemi genel itibariyle incelendiğinde, her iki yaklaşımın da geleneksel okul sistemlerine karşı çıktıkları, bu sistemleri çok şiddetli eleştirdikleri görülmektedir. Benzer biçimde her iki yaklaşımda da çocuğu tanımanın gerekliliği, çocuğun baskı altına alınmaması ve öğrenci aktivitesi söz konusudur. Bu yönleriyle her iki yaklaşımda, Rousseau'nun görüşlerinden esintiler olduğu söylenebilir. Örneğin Rousseau'nun öncelikli prensibi olan "hürriyet" prensibi, "çocuktan hareket" akımının da ilk ilkesi olmakta, Baltacıoğlu'nda olan “Şahsiyet” prensibine kısmen denk düşmektedir.

Bununla birlikte, Baltacıoğlu, şahsiyetin oluşmasında daha gerçekçi ve daha tabii bir yol izlemektedir. İşe, bütün cemiyetin değerlerini iştirak ettirmekte, o değerlerin yaşanmasını esas 
almaktadır. Hâlbuki diğer akımda çocuk, başlı başına bir boşluk diyebileceğimiz, amaçsız bir serbestiye itilmektedir. İkinci ilkeleri ele alınırsa, Baltacığlu'nun meseleye daha derin nüfuz ettiği söylenebilmektedir. Çünkü İçtimai Mektepte, çevre ilkesi gerçek bir cemiyetin gerçek bir çevresini, tabii bir hayatı ifade etmektedir. Çocuktan hareket akımında ise bir sunilik göze çarpmaktadır (Tozlu, 1989).

Çocuktan hareket akımında "hayata yakınlık" varken, Baltacıoğlu'nda hayatın kendisi vardır. Çocuktan hareket akımında, "tabii öğretim" ile çocuğun tabii güçlerine yönelmek kastedilmektedir; ancak "öğretim” kavramının kullanılmasının, gelenekselliğe işaret ettiği söylenebilir. Baltacıoğlu'nda ise "gerçek çalışmalarla" bir randıman ortaya konulması söz konusudur. Çocuktan hareket akımı, öğrencinin aktifliğini kabul eder; ancak çocuğun aktifliğinin sadece onun güçlerinin desteklenip geliştirilmesiyle sağlanacağını öne sürmektedir. Baltacığlu “çocuğu tekâmülüne uygun bir eğitimle meşgul edebilirseniz, aktif olabileceğini ancak aktivitenin çocuğun dışındaki merkezlerle sağlanamayacağını ifade" etmektedir. Ayrıca o verim ilkesi ile çalışmayı çocuğun ruhi bünyesine adapte etmektedir. Çocuğun neyi, nasıl yapayım, hangi çalışmadan başlayayım problemini de, kabiliyetlerine uygun bir "inisiye" işlemi ile çözmeye çalışmaktadır (Tozlu, 1989).

\section{2. "İş Okulu” Akımı ve Baltacıoğlu}

İş okulu akımı, 20. yüzyıldaki eğitim reformu akımları içerisinde en merkezi yer almış olanı, en yaygın ve en verimli olanıdır. Gerek kendi zamanında (1933'lere kadar) ve gerekse daha sonraki devrede, çağımızı her yönde çok güçlü bir şekilde etkilemiştir. Bu sebepledir ki, en geniş kapsamlı bir eğitim reformu akımı olarak karakterize edilebilmektedir. Zira bu akım, diğer akımları, kısmen ya da tamamen kendi bünyesine alabilmiştir. 1900-1933 yılları arasında, ilkokullar için neredeyse ideal olarak iş okulları modeli kabul edilmektedir (Aytaç, 2006).

İş okulu akımının önemli isimlerinden bir olan Kerschensteiner'a göre, kamusal okulların en yüksek görevi, öğrencide kendine has kişilik değerinin mükemmelleşmesinde, kendi payına düşeni yapması için gereken kuvvetleri geliştirmeleridir. Bunun dışında, okullardaki eğitimin görevleri genel itibariyle aşağıdaki gibi sıralanabilir (Kerschensteiner, 1947: 23):

- Mesleki eğitime ve öğretime hazırlama görevi

- Mesleki eğitimin ve öğretimin ahlakileştirilmesi görevi

- İçerisinde meslek etkinliğinin yapıldığı topluluğun ahlakileştirilmesi görevi 
Topluluğu teşkil eden bireyler ahlakileştirilmeden topluluğun ahlakileştirilmesi düşünülemeyeceğinden bireyin ahlaksal eğitimi de bu üç görev içinde bulunmaktadır. $\mathrm{Bu}$ üç görev aynı zamanda birbirine sıkı sıkıya bağlıdır. Öğrenciyi ahlaksal bir "meslek anlayışı" na götüren bir eğitimle yetiştirmeksizin, okula, topluluğun ahlakileştirilmesi hususunda işbirliği yapma görevi verilemez; öğrenciyi mümkün olabildiği kadar esaslı bir şekilde bir mesleğe hazırlamaksızın da ona bu meslek hakkında ahlaksal anlayış kazandırılamaz (Kerschensteiner, 1947).

Yine Kerschensteiner'a göre, zihni yeteneklerin gelişimi, ayrı bir iş dersi içinde el yeteneklerinin gelişimine ne kadar çok içten bağlanabilirse, halk okulunun örgütü o kadar iyi olur ve zihni yetenekler dahi o derece serbestlik ve güvenlikle gelişir. Ancak el işi etkinliklerinin herhangi birini genel öğretime bağlamak da doğru değildir. Dikkat edilecek ilk nokta, bir el etkinliği ne derece yüksek bir ilgi ve ısrarlı bir çabayla yapılırsa yapılsın ve ne kadar çok tekrar edilirse edilsin, bu etkinlik ancak, tinsel bir hazırlık yapmanın akışı söz konusu olduğunda eğitsel manada "iş" halini alabilir. Daha sonra bu etkinlik uygulanırken tekrar tekrar ele alınır ve yeni düşünme süreçlerine sebep olur. Örneğin bir çocuk bir mukavva kutu yapmak istiyor. İlk önce bunun şeklini, büyüklüğünü tayin ediyor; böyle bir kutu yapmak için ne gibi aletlere ve gereçlere ihtiyacı olduğunu, hatta bu gereçlerin miktarlarını düşünüyor. Hesaplar yapıyor, şemalar ve planlar çiziyor, gereçleri hiç ziyan etmeden kullanma çarelerini arıyor; işte bu tinsel hazırlık yapma safhasıdır ve işe asıl eğitsel değerini kazandıran da bu safhadır. Bu ilk karardan sonra el etkinliği başlıyor, yani hazırlanan plana göre mukavvalar kesiliyor ve yapıştırılıyor. Bu da uygulama safhasıdır ki, tinsel hazırlığın bir nevi akışından ibarettir. Fakat bu uygulama sırasında çeşitli vesilelerle tinsel etkinlik devam ettirilir, bu düşünme süreçleri el işinin eğitsel değerini arttırmaktadır (Kerschensteiner, 1947).

Kerschensteiner'da, iyi bir iş okulunun en önemli ayırıcı vasfı, yeni de olsa bir takım fikir yapılarını vücuda getirmek, ekonomik değer taşıyan el işleri yaptırmak değil; iş okulunun hakiki manası öğrencilerin, işlerini kendi kendilerine etkin olarak yaparken nesnellikleri ve kendi benliklerine sadakatları derecesinin ne kadar yüksek olduğunu- kendi kendilerini denetlemek suretiyle - öğrencilere yaşatarak öğretmekten ibarettir (Kerschensteiner, 1947). Bu noktadan hareketle, Kerschensteiner'ın derin bir “iş” anlayışı olduğu söylenebilir. Baltacıŏglu'nda ise, öğrencinin yaratıcıllğının gelişmesi, yeni fikirlerin üretimi ve ekonomik karşıllı̆ı olan el işleri önemli görülmektedir. Bu yönüyle ikisi arasında bir benzerlik vardır. 
Baltacıŏ̆lu ile benzer biçimde Kerschensteiner'a göre, okullarda iş alanları, işlikler, bahçeler, okul mutfakları, laboratuvarlar vs. bulunmalıdır ve öğrenciler buralarda aktif bir biçimde çalışmalar yapmalıdır. Yine her iki düşünür de "etkinlik yapmak için etkinlik yapılmasına" karşıdır. Kerschensteiner da bir işin eğitim ve öğretim değeri olabilmesi için sosyal değerlere aykırı olmaması, tamamlanma durumunda olması ve öğrencinin kendi kendini denetleyebilmesi gerekmektedir ve tamamlamaya elverişli olan işler genellikle teknik işlerdir. Baltacıoğlu ise, yapılan işte sosyal bir yön bulma taraftarıdır. Toplumda karşılığı olan gerçek bir çalışma süreci içinde bir eser meydana getirmek önemlidir. Her iki düşünürde de nesnel durumun göz önünde bulundurulması önemlidir. Bunun yanında hem Kerschensteiner hem de Baltacığlu öğretmenin niteliği konusunda benzer düşünmekte, öğretmenlerin ideal sahibi, fedakâr olmalarını arzu etmekte, bununla beraber öğretmenlerin teknik becerilerle donanmış olmalarını önemli görmektedir.

Tozlu'ya göre, Kerschensteiner ile Baltacıoğlu'nun görüşleri şöyle mukayese edilebilir: Kerschensteiner, işi zihni iş ve el işi diye iki kısımda düşünür, tefekkür tarihindeki düşünce ve faaliyet problemini, "iş”te, teori ve pratik olarak yeniden ele almaktadır. Fakat bu çetin problemi, iş yoluyla da açıklığa kavuşturamamaktadır. Böyle olmasına rağmen $\mathrm{O}$, iş ile karakter eğitimi de vermeye çalışmaktadır. Ayrıca Kerschensteiner, otomatik iş sistemlerinin karakter üzerindeki olumsuz etkilerini ele almış değildir. Baltacıŏ̆lu ise, başlangıçta teori ve pratik tartışmasına girmemekte, bu noktanın iyi anlaşılmasını istemektedir. O, en ilkel iş için bile fikrin olmadığı iddiasını kabul etmeyerek, bu iç içe oluşumu kendi bütünlüğü içerisinde görmeyi daha uygun bulunmaktadır. Kerschensteiner, giderek işe her şey gözüyle bakmaya başlar; ancak Baltacıoğlu'na göre, iş çok şeydir, ama her şey değildir (Tozlu, 1989).

Baltacıŏ̆lu'nun eserlerinde sıkça yer verdiği ve önemli gördüğü, iş okulu akımının değerli isimlerinden biri olan John Dewey (Aytaç, 2006)'den de mutlaka bahsetmek gerekmektedir. Dewey'e göre gerçek eğitim, çocuğun güçlerinin ortaya çıkarılması ile gerçekleşir ve eğitimsel anlamda şu üç keşif çok önemlidir (Dewey, 2010:182):

- İnsan beyni bir elektrik süpürgesi gibi öğrenmez; öğrenme ve anlama için sunulan gerçekler, bireyin önceki deneyimleriyle veya onun şimdiki ihtiyaçlarına bir miktar bağlantılı olmalıdır; öğrenme somuttan genele doğru ilerlemektedir, genelden özele değil. 
- Her birey birbirinden, sadece genel kapasite ve karakterleriyle farklı değildir, farklı1ıklar nispeten küçük yeteneklere ve karakteristik özelliklere yayılmaktadır, disiplinin hiçbir miktarı bunu imha edemez. Bunun en açık sonucu, benzer metotlar eğitimde benzer sonuçları muhtemelen vermez, ne kadar herkesi birbirine benzer yapmayı ümit edersek, metotlarda o kadar çeşitli ve bireysel olmalıdır.

- Bireysel çaba, bireysel ilgi olmaksızın imkânsızdır. Her beyin için kendi kendine eğitim sağlayabilecek bir ders olamaz. Eğer iş/eser bireyin ilgi alanına hitap etmiyorsa veya bağlantısı ya da onu ilginç kılan yan ürünleri yok ise birey en iyi çabasını ortaya koyamaz. Ne kadar çok çalışırsa çalışsın, çaba başarıyla sonuçlanmaz, ama dikkati toplanmadığı yerde tutabilmek için verilen ahlaki ve duygusal çaba da dağıtılmaktadır.

İlerlemeci eğitim akımı, eğitimcilerin, oldukça karışık, hızlı ve kalabalık uygarlaşma taleplerinin farkına varmalarının doğal bir sonucudur. Derslerde ve pratikteki değişikliklerle karşılanmıştır. Bu değişiklikleri etkili kılmak için, bir dersten sonra diğer dersi eklemekten başka şeylere de ihtiyaç duyulmaktadır. Yeni dersler birbirlerine bağlantılı bir şekilde ve de okul dışındaki yaşamla alakalı olarak öğrencilere sunulmalıdır. Bunun yanında psikoloji biliminin, bireysel öğrenme ve bireysel farklılıklar hakkındaki keşfettiklerini, sınıfta pratiğe koyma arzusu doğmaktadır (Dewey, 2010). Dewey’e göre öğrenmek, ancak "iş” ile yani yaparak mümkündür. Fakat bu "iş"in çocuğun canlı yaşantısı olarak kalabilmesi için, çocuğun kişiliğinin bir bütün olarak ona katılması gerekir. Onun içindir ki, Dewey'in iş okulundaki el işi çalışmaları, meslek okullarında olduğu şekilde kendi kendisinin bir amacı değil, tüm kişiliğin bir etkinlik alanı ve bu yolla da tüm dünya ile organik bir bağ olarak kabul edilmektedir. Böylece okul kendi bünyesindeki hayatı, etkinlik esasında yürüten, içinde yer aldığı toplumsal hayatı yansıtan “embriyonel bir birlik” halini almaktadır. Böyle bir okulda öğretim, "formel” esasta değil, "iş"e dayalı olarak "içerikli" bir esasta olacaktır (Aytaç, 2006).

Dewey’i, "pragmatist bir pedagog” (Baltacıŏlu, 1932a) olarak niteleyen Baltacıŏlu, O'nun eğitimin sosyal yanına eğilmesini olumlu görmekte; ancak teoride bu kadar ileri giden bu filozofun uygulama alanında randımanını tam olarak veremediğini düşünmektedir. Baltacıŏglu'na göre Dewey, el işi derslerini ele almaktadır. Çocuğun evrimi ile insanlığın evriminin paralel olduğuna inanmaktadır. Örneğin ağaç, mutfak, dokuma, terzilik, bahçe işlerini ele almaktadır. Bu işleri ilkel şekillerinden başlatıp en ileri, en yeni şekillerine kadar çocuklara yaptırmaktadır. Bu 
işler hep alaka merkezleri, ilgi ortamları olmaktadır. Bu ortamlar ile bilgiler verilmektedir. Uygulamanın aksaklıklarına ilişkin Baltacıoğlu'nun görüşleri şu şekildedir (Baltacıŏlu, 1964:72):

Bir kere teknik işlerin tarihteki evrimi üzerinde çalıştırmak yalnız tarih bilgisi bakımından yararlı olabilir. Bunun eğitimle doğrudan doğruya ilintisi yoktur. Batılıların sosyal sistem adını verdikleri bu pedagojinin sosyalliği yalnızca konularındadır, pedagojisinde ve eğitme tekniğinde değildir. Pedagoji sistemlerini sosyal yapan konuları değil, çocuğun sosyal bir insan olarak yetişmesini sağlayan sosyal şartlardır: Yetişmesi istenilen, çocuğun edinmesi gerekli olan sosyal kişilik, çocuğun yetişmesini sağlayacak sosyal çevre, bu çevre içinde sosyal kişiliğin doğmasını sağlayacak olan sosyal çalışma, böyle bir çalışmanın vereceği ekonomik, estetik, teknik, herhangi sosyal değer taşıyan sosyal bir randıman, çocuğun bu randımanını sağlayacak olan başlatıcı, alıştırıcı emeklemeler, denemeler. İşte bütün bu şartlar olmadıkça kurulan, kurulacak olan sistemler sosyal pedagoji sistemleri olamaz. Ateşi ilk bulan insanın işini tekrarlama, sosyalleşmek durumunda olan XX. yüzyıl insanının ne işine yarar?

İş okullarının bir diğer taraftarı sayılabilecek (Aytaç, 2006), Ferriere'ye göre öncelikle öğrencinin kendisi veya öğretmeni tarafindan öğrencide alaka uyandırılmalıdır. Bu alakayı uyandırdıktan sonra, alakayı tatmin etmek için işe geçilir. İşe geçebilmek için çeşitli gözlemler yapılır ve yapılan bu gözlemler tamamlanarak doğrudan doğruya yapılamayacak etkinliklerin boşluğu doldurulmaya çalışılmaktadır. Çocuğu zihnen ve bedenen faaliyete geçirebilmek için, çocuğa alakaları doğrultusunda el işleri yaptırılmalı ve çocuk müşahedelere sevk edilmelidir (Ferriere, 1931).

Yine iş okulu akımının diğer bir önemli ismi Decroly’ye göre çocuğun öğrenme ihtiyacı, hayvanlar, eşyalar ve hadiselerle alakalı merakını tatmin edebildiği derslerle, zaman ve mekân dâhilinde yapılan gözlemler ve alıştırmalarla temin edilebilmektedir. Ancak bu etkinlikler sınıf içi yapılabildiği gibi sınıf dışında gözlemler, gezi ve gezintiler biçiminde de olabilmektedir (Decroly, 1929). Decroly, çocuğun tabiatı ve onun görüntülerini derinliğine gözlemlemek suretiyle, onun eylemlerinde ve düşüncelerinde ne şekilde üretici olabileceğini göstermek istemektedir. Bu suretle Decroly metodunun dayandiğg ilkeler şu noktalarda toplanabilir (Aytaç, 2006: 115-116): 
- Okul, hayat yoluyla, hayata hazırlamalıdır. Okul okuma, yazma ve hesabın temel bilgileri, tarih, coğrafya ve cansız tabiat bilgileri vermek dışında, çocuğu daha küçük yaşlardan itibaren kendi çevresinin, tabii ve toplumsal çevrenin bilgisini kazanmaya yöneltmelidir.

- Gerçek bilgi, yalnızca zihni yeteneklerin etkinliği yoluyla kazanılmaktadır. Okullarda kitabi yoldan bilgi kazanmak değil, çocuğun kendi gözlem ve deneyimi yoluyla, gerçek dünyanın eşyaları ve şeyleri ile temasa geçmesi desteklenmelidir.

- Konular, ders plan ve programları, çocuğun spontan ilgisinden hareket etmelidir.

- Derslerin geleneksel düzeni değiş̧melidir. Her şeyi toplayan bir öğretim tarzıyla, çeşitli basamaklar arasında bağ kurulmalıdır. Ancak bu suretledir ki, "ilgi merkezi noktaları" oluşabilmektedir.

- Bir konuya duyulan ilgiden, spontan ilgiler gelişir. Okullardaki ödül verme ve sınav şekilleri değiştirilmelidir. Böyle bir öğretim yoluyla, yalnızca dünyanın bilgisi verilmekle kalmaz, ayrıca da birlikte yaşama duygusuna ve dayanışmaya ulaşılır. Böylece okul, ahlaki ve toplumsal eğitimin bir yuvası haline dönüşür.

Baltacıoğlu'na göre, Avrupa'da ün kazanmış önemli pedagoglardan olan Decroly, çok fazla eser ortaya koymasına rağmen, özgün bir eğitim anlayışına ve savunulabilir bir sisteme sahip değildir. Çünkü eğitim anlayışında asıl olan, çocuğu toplum hayatına alıştırmaktan ibaret olan teknik girişimdir ve bu durum Decroly de yoktur. Decroly eğitim gerçeğine ait birtakım dikkate değer sezgiler elde etmiş olmakla beraber pedagojik bir sistem sahibi değildir. Baltacıoğlu, Decroly'nin şahsından ve eserlerinden çok yararlandığını belirtmesine rağmen, Onu Rousseau ve Emile' inden daha ileri bulmamaktadır (Baltacıŏ̆lu, 1998).

Ferriere ve Decroly'nin pedagojik yaklaşımları genel itibariyle incelendiğinde, geleneksel eğitim yaklaşımlarına karşı çıkmaları bakımından Baltacıoğlu ile benzerlik göstermektedir. Ancak her iki yaklaşımın da alakayı merkeze almaları, Decroly'nin okulları, hayata hazırlık olan mekânlar olarak algılaması Baltacıŏglu'nda bulunmamaktadır. Baltacıŏglu'na göre, eğitim hayata hazırlık değil hayatın ta kendisidir ve eğitim yuvalarında "ilgi merkezleri" değil, "üretim merkezleri” bulunmalıdır.

"İ̧̧ okulu" mensupları, eski okul anlayışı yerine, işi ve iş aracılığıyla eğitimi koymakta ve bu duruma hayli önem vermektedirler. Baltacıoğlu ise, bunu yaratıcı bir hareket olarak kabul etmekte ve amaç olarak ileri sürmektedir. Çünkü onlar bu anlayışları ile faaliyet merkezlerini kabul ederler ve arzu ve istek önemlidir. Baltacığlu ise, "istihsal merkezleri vardır, alaka 
merkezleri yoktur” (Baltacığlu, 1932a, 1932b, 1938b, 1964, 1998) diyerek, eğitici olarak gerçek hayatı, hayatın tecellisi olacak şekilde okulu kabul etmektedir. İş okulu mensupları, bütün eleştirilerine rağmen okulu sanayileştirmekten ileri gidemezler, hatta çoğu defa işi, karton kutu, mukavva abajur ve tel sepet gibi suni bir safhaya ulaştırırlar, hayatın zaruretlerinden iş’i koparmaktadırlar. "İş okulu” mensupları, geliştirdikleri yeni eğitim anlayışlarının temeline "iş, faaliyet, cazibe..." gibi bireysel ve ruhsal unsurları koymaktadırlar. Baltacıoğlu'nun İçtimai Mektep'inde ise, toplumsal yaşam ve bu yaşamda yapılması gereken zaruretler yer almaktadır. İş, eğitim için, "İş okulu”"nda bir vesiledir. Onlar bu anlayışla derslerde sadece "el işi” faaliyetine yer vermektedirler. İçtimai Mektep'te, iş hayatla birlikte ele alınmakta ve hayatın mesleki zümrelerinin oluşumuna göre verilmektedir. Yani birey bu zaruretleri yaşamakta, bu yaşayışla birlikte eğitilmektedir. Bu anlayışta ayrı bir iş dersi ve tabiat dersi bulunmamaktadır. Yalnız içtimai bir faaliyet vazifesi vardır. Gerçek çevrelerde çocuklar toplumsal değeri olan işleri görmektedirler. Eğitimin verimi de bu işlerin toplumsal açıdan ortaya koyacakları verimle ölçülebilmektedir. Bunun için çocuklara gerçek cemiyetin, gerçek mesleki zümrelerinin gerekleri yaşatılmalıdır (Tozlu, 1989). Tüm bunlar dikkate alındığında, Baltacıŏglu'nun eğitim sistemi ile “iş okulu” yaklaşımı arasında bir hayli farklılık olduğu söylenebilir.

\section{3. "Üretim Okulu” Akımı ve Baltacıoğlu}

İş okulu akımı, "Üretim okulu” akımında köklü bir değişime uğramakla birlikte, bu yolla eğitime, ekonomik iş, hatta endüstriyel iş sokularak, ona sınıfçı bir karakter eklenmiştir. Üretim okulu akımı, K. Marx (1818-1883)'ın düşüncelerinden ortaya çıkmakla birlikte, ilk defa en geniş sınırları içinde ihtilal sonrası Rusya'da gerçekleştirilmiştir. Daha sonra "Politeknik eğitim" sistemi olarak bütün sosyalist ülkelerde gerçekleştirilmeye çalışılmıştır (Aytaç, 2006). Politeknik eğitimde, okullarda verilen dersler ile üretim alanlarındaki uygulamalı çalışmaların bir sentezi yapılmak istenmiştir (Demirtaş, 2002). Bu politeknik okul reformlarında hemen bütün sosyalist ülkelerde başlıca ortak özellikler, şu ana noktalarda toplanmaktadır (Aytaç, 1971:58-59):

a) El işi dersleri: Çocuklar 6-7 yaşlarından itibaren el işi derslerine başlamaktadırlar. Genel itibariyle çocuklardaki serbest yaratıcılı̆̆ı, fanteziyi ve bunlara benzer özellikleri geliştirmek ve bu arada da belirli bir ölçüde olmak üzere el işi becerikliliğini sağlamaya çalışmak ile daha sonraki teorik ve pratik yöndeki üretim çalışmalarına hazırlayacak tarzda bir ön kademe düzenlemek, amacıyla işe koşulmaktadır. 
Ismayıl Hakkı Baltacıoğlu’nun Özgün Eğitim Sistemi ve Bu Sistemin Zamanın Çağdaș Eğitim Yaklaşımları ile Karşılaştırılması

b) Teknik resim: $\mathrm{Bu}$ ders, 7. sinıftan itibaren hem genel hem de mesleki ve teknik öğretim okullarında, haftada birer saat olmak üzere yapılmaktadır.

c) Atölyelerde ve üretim işletmelerindeki pratik çallş̧malar: Öğrenciler 5. sınıftan itibaren her öğrenim yılı sonunda endüstriyel ve tarımsal işletmelerde, ikişer hafta tutarında bir "üretimde pratik çalışma" yapmak zorundadırlar. Bunların amacı, öğrencilere önemli üretim alanlarında genel mahiyetteki teknik bilgileri kazandırmaktır.

Üretim okulu akımının önemli isimlerinden biri Blonski'dir. Blonski, eğitim reformu konusundaki görüşlerini ayrıntılı olarak "iş okulu" adlı ana eserinde açıklamıştır. Ancak Blonski (1990:90)'ye göre, “iş okulu yoktur, Marksist iş okulu” vardır ve bu okul diğer iş okulu kavramlarından farklıdır, burada endüstriyel üretim söz konusudur. Aytaç'a göre de, Blonski'nin bu ana eseri "iş okulu" adını taşımakla birlikte, burada aslında bir "üretim okulu" nun teorisi ve uygulamasıyla ilgili esaslar ele alınmaktadır. Çünkü onun taslağını çizdiği iş okulu, ekonomik ve sosyal yönden zorunlu iş'i, esas olarak alan bir okuldur (Aytaç, 2006).

Blonski’ye göre üretici iş, mevcut nesneleri, insana yararlı nesnelere dönüştüren insan faaliyetidir. $\mathrm{Bu}$ açıdan iş eğitimi, çocuğun mevcut nesnelerden insan için yararlı olan, yani kullanım değeri olan nesneleri yaratacak biçimde amaca yönelik faaliyette planlı ve düzenlenmiş alıştırma görmesidir. Çocuk, iş eğitimi görmekle, doğayı insanların gereksinimleri doğrultusunda zorlayabilen bir varlık olarak gelişir ve iş eğitimi doğaya egemen olma eğitimidir. İş eğitiminde en önemli etken, çocukta iş araçlarını kullanma yeteneğini geliştirmektir. Dolayısıyla iş eğitiminin özünü, iş araç ve aletlerini, iş tekniklerini kullanma yeteneğini geliştirme oluşturur (Blonski, 2003).

Blonski'nin iş temelli yeni okulu şu kademelerden oluşmaktadır (Blonski, 2003):

1. Okul öncesi eğitim (3-7 yaş): Bu eğitimde, çocuk oyunundan hareket edilmelidir. İlk çocukluk dönemi oyunlarının genel olarak belli nesnel bir sonucu amaçladığı göz önüne alınmalıdır. İlk çocukluk dönemi oyunları, çocuğun özgür uğraşısıdır. Bu nedenle okul öncesi eğitim sorunu, küçük çocuğun özgür, doğal oyunlarını pedagojik bir biçimde seçme ve pedagojik açıdan amaca yönelik olarak organize edilmesinden oluşmaktadır.

2. Endüstriyel iş okulu 1. Kademe (8-13 yaş): Bu okullarda çocuklar çeşitli çalışma imkânları ve araçlarına sahiptirler. Bu iş komününde çocuklar, yetişkin eğitimcilerin 
katılımıyla, okul tarımı yaparlar, yemek pişirirler, okul binalarıyla ilgilenirler, diğer eve özgü işler yaparlar, serbest zamanlarını kültür dolu bir biçimde geçirirler, okurlar, yazarlar, estetik değerler yaratırlar, şarkı söylerler, gezilere çıkarlar ve oyun oynarlar. Bazı büyük çocuklar atölyelerde çalışırlar ve bu atölyeler kısmen okullara bitişik vaziyettedir.

3. Endüstriyel iş okulu 2. Kademe (14-18 yaş): Bu kademede çocuklar, artık fabrika çalışması içine girerler. İdeal şekliyle, işletmedeki faaliyet ile gençlik evindeki uğraşıların ve serbest zaman faaliyetlerinin organik kaynaşması söz konusudur. Gençlik evinde gençler, üretici işin en iyi şekilde anlaşılmasına yarayan bilimsel çalışmalar ve sanat etkinliklerine katılırlar. Gençlerin bir gruptan başka bir gruba akla yatkın bir biçimde geçişi sağlanmalıdır. Müzik ve şarkı söyleme, tiyatro, heykel ve resim, edebiyat kollarının olduğu varsayılsın. Bu kollardaki gençlerin faaliyetleri, her birisi en az yarıyıl süreyle bir kolda faaliyet gösterecek biçimde düzenlenir. İkinci aşamada okulda estetik için öngörülen zamanın yarısı çeşitli sanat türlerine giriş çalışmasına ayrılırken, geri kalan sürede de gencin seçtiği bir sanat dalında derinlemesine etkinlik yapması sağlanır. Aynı şey, spor için de geçerlidir. Fabrikada çalışma da benzer biçimde organize edilir. Örneğin genç, yılda iki kez başka bir atölyeye geçirilmesi ve bu şekilde tüm okul çalışma süresinin yarısını geçirmesi suretiyle iş alanlarını değiştirir. Sonunda da genç, bir yandan çeşitli üretim alanlarını tanır, diğer yandan da belirli bir meslekte uzmanlaşma olanağı elde eder. Örneğin bir yandan tekstil endüstrisinden metalürji ve kimya endüstrisine, buradan da inşaata ve (yazın) tarım endüstrisine geçer, diğer yandan da ağaç işlemeciliğinde uzmanlaşır.

Yukarıdaki açıklamalar incelendiğinde Blonski’nin “üretici iş” ile “eğitimi” birleştirdiği görülecektir. Benzer biçimde yine "üretim okulu” akımı savunucularından biri de, aynı zamanda Blonski ile de birlikte çalışmış olan Krupskaya'dır. Krupskaya’ya göre okul, öğrencilerin üretim üzerine ilgilerini çekmeli ve üretimin mümkün olan en yüksek seviyeye çıkmasını sağlamalıdır. Diğer yandan fabrika yetiştirme okulu öğrenciye, fabrika veya iş yerlerinde emeğin örgütlenmesini tanıtmalıdır. Okul, öğrenciye zorunlu ve sağlıklı çalışma koşullarını yaratmayı öğretmeli; emeğin korunmasını ve herhangi bir işletmede özellikle tekstil üretiminde endüstriyel güvenliğin temellerini tanıtmalıdır. Son olarak fabrika yetiştirme okulu öğrencilere, yurttaki ve dünyadaki sendika hareketlerinin tarihini öğretmeli ve işçilerin, özellikle tekstil işçilerinin dünya 
çapında yürüttükleri savaşımı anlatmalıdır. Bütün bunlar öğrenciye, dar bir meslek vermemekte, tersine geniş politeknik eğitim; fabrikaya deneyimsiz bir yardımcı ve engelleyici bir işçi olarak değil, sadece kısa süreli uzmanlaşma kursu olması gereken olgun ve usta bir işçi olması için gereken çalışma alışkanlığı vermektedir (Krupskaya, 1994).

Krupskaya, her ne kadar üretim okulu akımını savunsa da, görüşlerinin Blonski kadar derin ve kapsamlı görünmediği söylenebilir. Bu sebeple, Blonski ve Baltacıoğlu'nun eğitim yaklaşımlarının karşılaştırılmasında yarar vardır.

Öncelikle her iki yaklaşım da geleneksel okul anlayışına karşıtlığı bakımından benzer düşünmektedirler. Ancak bu okul anlayışlarına karşı önerdikleri sistem, kendi paradigmalarına göre farklılıklar göstermektedir. Blonski, Marksist bir düzen anlayışıyla okulları şekillendirmek isterken, Baltacıoğlu'nun böyle bir dünya görüşü bulunmamaktadır. Blonski, "endüstriyel iş okulu" anlayışından hareket ederek, "üretici iş" ile "eğitimi” birleştirmek istemekte ve komünlere ayırdığ1 öğrencilerden endüstriyel üretim beklemektedir. Baltacıoğlu'nda ise öğrenciler, komünleştirilmez, gerçek toplum içerisinde, toplumsal hayatın zorunlu kıldığı "iş" lerle meşguldürler ve maddi-manevi bütün değerlere ilişkin çalışmalar gözetilmektedir. Blonski, ders içeriklerinin oluşturulmasında endüstrinin ihtiyaçlarını temel alırken, Baltacıoğlu günlük hayatta karşılaşılan gerçek ve sosyal ihtiyaçlar üzerinde durmaktadır. Her iki düşünürde de teknik bakımdan güçlü, işbirlikli çalışan öğrenciler önemli görülürken, Blonski, işbirlikli çalışmanın, kolektif ruhun ancak işletmelerde gerçekleştirilebileceğini düşünerek Baltacıŏlu'ndan ayrılmaktadır. Baltacı̆̆glu, geleceği sağlam karakterli, şahsiyet sahibi bireylerde görürken, Blonski’ye göre endüstriyel kolektif kültüre sahip bireyler geleceği inşa edebilir (Tozlu, 1989).

Çocuğun yeteneklerine dikkat etmek ve saygı duymak noktasında ikisi de hemfikirdir. Ancak, Blonski'nin düşüncesi adına çocuğun yeteneklerini yönlendirme çabasına karşılık, Baltacıŏglu çocuğun yeteneklerinin serbestçe serpilip gelişmesini ve bu gelişmeyi sağlayacak ortamın var edilmesini savunmaktadır. Eğitim, Blonski de gayet dar bir kalıp içerisinde alınmaktadır ve sadece endüstriyel iş vasıtası ile olabilmektedir. Baltacıoğlu ise, eğitime böyle dar ve kesin sınır çizme yerine, onu çok geniş bir perspektifle ele almayı tercih etmektedir (Tozlu, 1989).

Baltacıŏglu'nda cemiyet, yaşayan ve var olan cemiyettir. İdeal de, bu tabii cemiyette oluşan tabii bir idealdir. Bunun için Baltacıoğlu'nda, Blonski de rastlanan zorlama ve yapaylıklara rastlanmaz. Blonski de bu düğüm, onun insana bakışının ve insanı anlamlandırışının 
zaruri bir sonucudur. Blonski tabii insanı, yani yaşayan ve varolan insanı, bütün güçleriyle birlikte olduğu gibi ele almaz, tek yönlüdür. Baltacıoğlu'nda ise insan, "biyo-psiko-sosyolojik" verilerin 1şığı altında değerlendirilmektedir. Burger'a göre de, iş pedagojisi, hürriyet pedagojisine kayıtsız ve şartsız taraftarlık edememektedir. Çocukluk devrinin kendine mahsus hakları ve kıymetleri vardır. Bunu tanımak ve takdir etmek gerekmektedir. Çocuğun eğitiminde yalnız yetişkinlerin ihtiyacını düşünmek ve ona göre tedbir almak doğru değildir. Bu yönleriyle iş okulunun kendi kendine faaliyet prensibinde çocuklara gerek ruhi ve gerek psiko-fizik işler yaptırılırken göz önünde tutulmalıdır (Burger, 1976). Blosnki’ye göre gençler hem fabrikada çalışacak, hem de orada bilimsel formasyon kazanmış işçiler sayesinde, ilmi istihsale yöneleceklerdir. Bu husus sadece nazariyede olabilmektedir. Çünkü söz konusu gençler, bilimsel formasyon sahibi işçilerin nezareti altında, olsa olsa üretici birer teknik adam olurlar. İlmi istihsal edebilecek âlim seviyesine ulaşamazlar. Ancak ilim hayatı yaşayan, ilmi prosedür ve çalışma sistemine alim gibi iştirak eden fertler, ilmi istihsale yönelebilmektedirler (Tozlu, 1989).

Yukarıdaki açıklamalar dikkate alındığında, Blonski ve Baltacıoğlu'nun eğitim yaklaşımları arasında genel itibariyle benzerlikler olsa da, Baltacıoğlu'nun "İçtimai Mektep" sisteminin ideal, içerik ve işleyiş bakımından Blonski’nin eğitim yaklaşımlarına kıyasla farklı olduğu görülmektedir.

\section{Sonuç}

$\mathrm{Bu}$ çalışmada Baltacıoğlu'nun eğitim görüşleri ve İçtimai Mektep sisteminin ilkeleri açıklanarak, zamanın çağdaş eğitim ekolleri ile kıyaslamasının yapılması amaçlanmıştır. Bu amaç doğrultusunda varılan çıkarımlar, Baltacıoğlu'nun Şahsiyet Pedagojisi dediği pedagojik sistemi ve bu sistemin uygulanabileceği okul olan İçtimai Mektep'in, ilkeleriyle bütün olarak değerlendirildiğinde, orjinal bir yaklaşım olduğu ve çağdaş pedagojik yaklaşımlarla benzerlikler içerse de özünde temel farklılıklar barındırdığını ve günümüzde halen geçerliliğini sürdürdüğünü ortaya koymaktadır. Karagöz (2014)'e göre de, Baltacıoğlu tarafından neredeyse bir asır öncesinden ortaya konan düşüncelerin önemi, yazıldığı dönemin eğitim ortamı özellikleri ile günümüz eğitim ortamı özelliklerinin benzerlik göstermesinden ileri gelmektedir ve bu bağlamda geçmişte ortaya konulan bu düşüncelerin günümüz eğitim problemlerine yönelik aç1lımlar içermesi Baltacıoğlunun ileri görüşlülüğünün bir neticesi olarak değerlendirilebilir. 
Hayatı boyunca sayısız esere imza atan, genel olarak eski düzenin aksaklıklarına karşı çıkan ve bir "inkılap" peşinde koşan Baltacıŏlu, idealin ne olması gerektiğine eserleriyle yanıt vermiş̧tir (Altın, 2014). Bu doğrultuda, Baltacıoğlu'nda İçtimai Mektep fikri, önce toplumsal dayanışmacılık şeklinde doğmaktadır. Toplumsal dayanışmacılığın ilk temsilcileri de Rousseau, Kant ve A. Comte gibi filozoflardır. Filozoflarca ortaya atılan sosyal terbiye, pedagoglarca önce fikir terbiyesi olarak anlaşılmaktadır, sonra da duygu eğitimine önem verilmektedir. Üçüncü aşamada ise, çocukları cemiyet hayatı ile eğitmeyi düşünmektedirler. Bunun için okula bir takım yardım kurumları, dini ayinler ve model meslek zümreleri sokulmaktadır. Bütün bu anlayışları dikkatlice ve titizce tetkik eden Baltacığlu, önemli eksikliği hemen sezmiştir. Ona göre asli olan okulun toplumsal hayatını değiştirmektir. Söz konusu filozoflardan özellikle Durkheim'ı ve Rousseau'yu tahlil etmiş ve şahsiyete ait ilhamını da Rousseau'dan almıştır (Tozlu, 1989).

Şahsiyet pedagojisi temelinde oluşan Baltacıoğlu'nun İçtimai Mektep anlayışı beş ana ilke ile temellendirilmiştir. Bunlar; şahsiyet, çevre, çalışma, verim ve başlatma ilkeleridir (Baltacıoğlu, 1942). Bu ilkeler tek tek ele alındığında bunların ilk defa Baltacıoğlu tarafından ortaya konulmadığ1 görülecektir. Çünkü her ilkeyi birçok düşünürde ve sistemde bulmak mümkündür. Mesela, şahsiyet ilkesine Rousseau'da hürriyet ilkesi olarak, Durkheim'da ise başka bir ad altında rastlamak mümkündür. Ayrıca çevre ilkesi Rousseau'da, Pestallozzi'de, Froebele ve Montessori'de, çalışma (travay) ilkesi ise, faal okul taraftarlarında, inisiyasyon ilkesi de ilkel cemiyetlerde topluma giriş ayini şeklinde görülmektedir. Ancak bu beş ilkeyi, belirli bir sistem içerisinde ilk defa kullanan Baltacıoğlu'dur. Bunun için sisteminin, ilkeleri itibariyle de orijinal olduğu ifade edilebilir (Aytaç, 1984; Tozlu, 1989). Çağdaş eğitim akımları ve Baltacıŏglu'nun eğitim sistemi karşılaştırıldığında, geleneksel okul sistemlerine karşı çıkmaları, eğitim uygulamalarında çocukların etkin bir biçimde çalışmalarının öncelenmesi noktalarında benzerliklerin olduğu görülmekte; ancak bu sistemlere yakından bakıldı̆̆ında Baltacıoğlu'nun eğitim yaklaşımındaki farklılıklar göze çarpmaktadır. Baltacıoğlu'nun temel hareket noktası, bireyde sosyal şahsiyetin (mesleki şahsiyet/meslek adamı) mümkün olduğu derecede oluşturulmasıdır ve bu durum amaç olarak ortaya konulur. Sonrasında bu şahsiyetin evrimine uygun gerçek bir çevre, bu çevrede gerçek tekniklerle aktif olarak çalışarak kullanılabilir ürünler oluşturacak öğrenciler ve öğrencilerin yapması gereken temel çalışmalar söz konusudur. $\mathrm{Bu}$ adımlar ve zorunluluklar birlikte değerlendirildiğinde Baltacıoğlu'nun eğitim sistemin ilkeleri, diğer çağdaş eğitim sistemlerinde bu bütünlük içinde yer almamaktadır. 
Baltacıŏlu'nun özgün eğitim anlayışı üzerinde yeteri kadar durulmamış olması eğitim tarihimiz açısından büyük bir eksiklik olarak karşımıza çıkmaktadır. Çağdaş eğitim akımlarıyla kıyaslandığında daha kapsamlı ve gerçekçi görülen Baltacıŏ̆lu'nun eğitim anlayışının uygulanabilir alanlardan başlayarak sahalarda test edilmesi önerilmektedir.

\section{Kaynakça}

Altın, H. (2014). II. Meşrutiyetten Cumhuriyete İsmail Hakkı Baltacıoğlu ve onun eğitim ve eğitimci kavramları ile ilgili düşünceleri. Tarih Araştırmaları Dergisi, 33 (55), 219-252.

Aydın, İ. (2010). Alternatif okullar (3. Bask1). Ankara: Pegem Yayınc1lık.

Aytaç, K. (1971). Politeknik eğitim reformları (teori ve uygulamalar). Ankara: Ankara Üniversitesi Basımevi.

Aytaç, K. (1984). İsmayıl Hakkı Baltacıŏlu. Ankara Üniversitesi Ĕ̆itim Bilimleri Fakültesi Dergisi, 17 (1), 237-248.

Aytaç, K. (2006). Çăğdaş eğitim akımları (Yabancı ülkelerde). Ankara: Mevsimsiz Yayınları.

Aytaç, K. (2012). Avrupa eğitim tarihi. Ankara: Phoenix Yayıncılık.

Baltacıoğlu, I.H. (1930). Hususi tedris usulleri. İstanbul: İlhami Matbaası.

Baltacioğlu, I.H. (1932a). İçtimai mektep. İstanbul.

Baltacioğlu, I.H. (1932b). Terbiye. İstanbul.

Baltacıoğlu, I.H. (1935). Tarih ve Terbiye. İstanbul: Semih Lütfi Bitik ve Basımevi.

Baltacıoğlu, I.H. (1938a). Toplu Tedris. İstanbul: Sebat Basımevi.

Baltacıoğlu, I.H. (1938b). Felsefe. İstanbul: Sebat Basımevi.

Baltacıŏlu, I.H. (1942). İçtimai mektep (2. Baskı.). Ankara: Maarif Matbaası.

Baltacıŏlu, I.H. (1944). Rüyamdaki Okullar. İstanbul: Ahmet İhsan Matbaası.

Baltacıŏglu, I.H. (1962). Ezber yerine travay. Türkiye Muallimler Birliği Yayın Organı, 16 (186187), 1-2.

Baltacıŏglu, I.H. (1964). Pedagojide ihtilal. İstanbul.

Baltacıoglu, I.H. (1995). Talim ve terbiyede inkılâp. Rıdvan C. ve Kıncal R.Y. (Yayına hazırlayanlar) İstanbul: Milli Eğitim Bakanlığı Yayınları.

Baltacıoğlu, I.H. (1998). Hayatım. Baltacıŏ̆lu, A. Y. (Yayına hazırlayan). İstanbul: Dünya Yayıncilik.

Blonski, P.P. (1990). İş okulu eğitim sorunlarının çözüm yöntemi olarak Marksizm. (1. Bask1). Yılmaz, T. (Türkçeye çeviren). İstanbul: Sorun Yayınları. 
Ismayıl Hakkı Baltacıoğlu'nun Özgün Eğitim Sistemi ve Bu Sistemin Zamanın Çağdaş Eğitim

Yaklaşımları ile Karşılaştırılması

Blonski, P.P. (2003). İş okulu eğitim sorunlarının çözüm yöntemi olarak Marksizm. (2. Baskı).

Yılmaz, T. (Türkçeye çeviren). İstanbul: Sorun Yayınları.

Burger, E. (1976). İş pedagojisi. Kanad, F. (Çeviren). Ankara: Milli Eğitim Basımevi.

Decroly, O. (1929). Tedrisatta toplulaştırma işi. Nami, K. (Türkçeye çeviren). İstanbul: Devlet Matbaas1.

Demirtaş, H. (2002). Eğitim üzerine. Toprakçı, E. (Editör). Ĕgitimde alternatif paradigmalar. Ankara: Ütopya Yayınc1lık, 321-367.

Dewey, J. (2010). Günümüzde eğitim. Ratner, J. (Editör). Ata, B. ve Öztürk, T. (Çeviri editörleri). Ankara: Pegem Yayıncılık.

Ergün, M. (1996). Ismayıl Hakkı Baltacıoğlu, yaşamı ve hizmetleri. F. Oğuzkan.(Editör). İ. Hakkı Baltacıoğlu’nun yaşamı ve hizmetlerine toplu bir bakış. Ankara: Türk Eğitim Derneği Yayınları, 9-18.

Ferriere, A. (1931). Faal mektebin tatbikatı. Gümüşhane Orta mektep müdürü Mustafa. (Türkçeye çeviren). İstanbul: Devlet Matbaası.

Kanad, F. (1963). Pedagoji tarihi. İstanbul: Milli Eğitim Basımevi.

Karagöz, S. (2014). Çağdaş pedagojik anlayışa uygun üç düşünür ve üç yazı (1910-1919) ( Sâtı Bey, İsmail Hakkı (Baltacıoğlu), Halil Fikret (Kanat)). Türkiye Sosyal Politika ve Çalışma Hayatı Araştırmaları Dergisi, 4 (7), 83-99.

Kerschensteiner, G. (1947). Işs okulu kavramı. Gündüzalp, F. (çev.). Ankara: Milli Eğitim Basımevi.

Krupskaya, N.K. (1994). Eğitim Üzerine. (4. Bask1). İstanbul: Yorum Yayınları.

Rousseau, J.J. (2013). Emile “Bir çocuk büyüyor”. Akagündüz, Ü. (Yayına hazırlayan). İstanbul: Selis Yayıncılık.

Tozlu, N. (1989). Ismayıl Hakkı Baltacıoğlu'nun ĕgitim sistemi üzerine bir araştırma. İstanbul: Milli Eğitim Bakanlığı Yayınları.

Ülken, H.Z. (1998). Türkiye’de çağdaş düşünce tarihi. (5.bask1). İstanbul: Ülken Yayınları. 